Vol. 2 | No. 4 | 2021 | Hal. 270-273

\title{
TINGKATKAN MUTU PENDIDIKAN DI ERA DARING COVID-19 DENGAN MEMBENTUK RUMAH BELAJAR BAGI SISWA SD
}

\author{
Arfan Kaimuddin*, Rika Sari Maharani, Riki Wibowo, Rofik Kurrohman, Muhammad \\ Fakhrurrozy, Angelina Septa, Dian Aditya Arif, Risalatul Aulia, Ririn Nur Afifah, Astro \\ Dwi Putra, Kemal Maulana Anam, Fizar Wildan Setiawan \\ Fakultas Hukum, Universitas Islam Malang \\ *korespondensi email: arfan@unisma.ac.id
}

\begin{abstract}
ABSTRAK
Penyebaran Corona Virus Disease (Covid-19) yang telah ditetapkan sebagai pandemi oleh World Healt Organization (WHO) pada tanggal 11 Maret 2020 semakin meluas. Pendidikan menjadi salah satu hal yang terdampak covid-19 yang menyebabkan berubahnya sistem pembelajaran dari tatap muka menjadi pembelajaran jarak jauh dengan daring. Pendidikan memiliki peran penting untuk kemajuan bangsa karena pendidikan memiliki fungsi untuk membentuk karakter peserta didik untuk diaplikasikan dalam kehidupan bermasyarakat. Dalam Pasal 1 Undang-Undang Nomor 20 Tahun 2003 juga disebutkan bahwa Pendidikan adalah usaha sadar dan terencana untuk mewujudkan suasana belajar dan proses pembelajaran agar peserta didik secara aktifmengembangkan potensi dirinya untuk memiliki kekuatan spiritual keagamaan, pengendalian diri, kepribadian, kecerdasan, akhlak mulia, serta keterampilanyang diperlukan dirinya, masyarakat, bangsa dan negara. Dengan adanya sistem pembelajaran daring ini peserta didik bisa belajar kapan pun dan dimanapun tanpa terbatas oleh ruang dan waktu. Namun dengan adanya sistem ini peserta didik dihadapkan dengan beberapa masalah salah satunya adalah kurangnya motivasi belajar peserta didik yang membuat peserta didik tidak memahami materi yang diberikan oleh guru. Metode yang dipakai untuk penelitian ini adalah metode diskusi dimana melibatkan siswa untuk belajar memecahkan masalah. Tujuan dibentuknya rumah belajar ini adalah untuk meningkatkan kembali semangat belajar para siswa agar kelak menjadi penerus bangsa yang berkarakter dan cerdas.
\end{abstract}

Kata Kunci: rumah belajar; pendidikan; covid-19

\section{PENDAHULUAN}

Pendidikan merupakan aspek yang sangat penting bagi suatu bangsa karena pendidikan memegang peran yang sangat penting dalam pembentukan karakter generasi penerus bangsa (Suhartoyo et al., 2020). Dalam Pasal 1 Undang-Undang Nomor 20 Tahun 2003 Pendidikan adalah usaha sadar dan terencana untuk mewujudkan suasana belajar dan proses pembelajaran agar peserta didik secara aktif mengembangkan potensi dirinya untuk memiliki kekuatan spiritual keagamaan, pengendalian diri, kepribadian, kecerdasan, akhlak mulia, serta keterampilan yang diperlukan dirinya, masyarakat, bangsa dan negara.

Pandemi covid-19 ini telah memberi gambaran atas masa depan dunia dimana segala aktivitas dilakukan dengan bantuan teknologi. Namun, tatap saja teknologi tidak bisa menggantikan peran seorang guru, dosen, maupun interaksi langsung antara pengajar dengan pelajar. Situasi pandemi ini menjadi tantangan tersendiri bagi guru, murid maupun 
orang tua dalam menggunakan teknologi untuk melaksanakan dunia Pendidikan (Rosyidah et al., 2021).

Seperti yang kita ketahui, Indonesia merupakan salah satu negara yang terkena dampak dari covid-19. Sehingga para pelajar maupun mahasiswa harus melaksanakan kegiatan pembelajaran secara daring atau online. Pada masa pembelajaran jarak jauh atau daring, banyak sekali siswa yang kesulitan untuk memahami setiap materi yang diberikan oleh guru. Bahkan ada beberapa anak yang merasa bosan dengan pembelajaran daring. Dan tidak sedikit anak yang mengeluh karena tugas yang diberikan oleh guru lebih banyak daripada saat melakukan pembelajaran secara offline (Nafrin \& Hudaidah, 2021).

Pembelajaran dengan metode daring ini memiliki kelebihan dan kekurangan. kelebihan dari pembelajaran daring ini adalah lebih praktis bisa dilakukan dimanapun dan kapanpun. tetapi dibalik kelebihannya terdapat kekurangan dari pembelajaran daring tersebut yang seringkali dikeluhkan oleh para siswa yakni keterbatasan kuota internet dan kendala sinyal yang terkadang menjadi hambatan saat proses pembelajaran daring. Kebosanan belajar secara daring juga terkadang membuat murid tidak mendengarkan materi yang disampaikan oleh guru dan menjawab pertanyaan dengan asal karena mereka hanya berdiam diri dirumah dengan menatap layar ponsel masing-masing tanpa adanya interaksi baik antara guru dengan murid maupun dengan sesama murid saat seperti pembelajaran offline.

Maka dari itu mahasiswa KSM-Tematik Universitas Islam Malang membuat program kerja Rumah Belajar bagi para siswa kelas 1-6 sekolah dasar dengan tujuan agar para siswa bisa melakukan pembelajaran tanpa adanya rasa bosan dengan suasana baru dan tetap mematuhi protokol kesehatan yang ada sehingga setiap materi bisa dipahami dengan mudah oleh siswa agar kelak bisa menjadi penerus bangsa yang berkarakter dan cerdas.

\section{METODE}

Dalam pelaksanaan program kerja rumah belajar ini, pelaksana menggunakan metode diskusi dimana melibatkan siswa untuk belajar menyelesaikan masalah. Penerapan diskusi dilakukan dengan membentuk kelompok sesuai dengan tingkat kelas masing-masing mulai dari kelas 1-6 sekolah dasar. Tujuan utama dari metode diskusi ini adalah untuk menyelesaikan, menjawab dan memahami suatu permasalahan sehingga para siswa bisa membuat suatu keputusan mengenai permasalahan tersebut. Sebelum diskusi dilakukan, para pelaksana akan menjelaskan beberapa materi yang diperlukan dengan acuan buku ajar yang sudah disediakan oleh sekolah. Selanjutnya siswa diberi kesempatan untuk menanyakan materi apa yang sekiranya belum bisa dipahami. Setelah diskusi selesai dilakukan, pelaksana akan memberikan pertanyaan kepada masing-masing peserta untuk mengetahui perkembangan siswa selama jam pembelajaran dilakukan.

\section{HASIL DAN PEMBAHASAN}

Adanya pandemi covid-19 telah memberikan pengaruh yang besar terhadap sektor pendidikan di Indonesia. Pendidikan sekolah dasar adalah salah satu yang paling terdampak oleh kondisi pandemi saat ini. Sejak adanya pandemi covid-19 ini pemerintah mewajibkan seluruh siswa untuk belajar dari rumah dengan daring agar para siswa tetap mendapatkan haknya terkait layanan pendidikan.

Selama pembelajaran jarak jauh dengan daring banyak dari siswa yang mengeluh karena merasa bosan dan tidak memahami materi yang diberikan. Keluhan itu juga datang dari orang tua murid yang tidak sanggup untuk mendampingi anaknya belajar dikarenakan sang anak sendiri belum mengerti setiap materi yang ada (Palupi, 2020). 
Oleh karena itu, mahasiswa KSM-Tematik 59 Unisma membuat gagasan dengan membentuk rumah belajar bagi siswa sekolah dasar yang ada di Desa Gunungrejo, Kecamatan Singosari, Kabupaten Malang dengan tujuan agar para siswa tidak bosan sehingga setiap materi yang diberikan bisa dipahami.

Dari hal tersebut diatas, maka hasil dan pembahasan ini dapat diklasifikasikan sebagai berikut:

\section{Pengenalan Rumah Belajar Oleh Mahasiswa Kepada Para Murid dan Orang Tua}

Untuk memperkenalkan rumah belajar, mahasiswa mendatangi rumah warga yang ada di Desa Gunungrejo untuk membagikan brosur beserta penjelasan mengenai rumah belajar yang akan didirikan oleh mahasiswa selama melaksanakan KSM-Tematik disana. Mahasiswa juga menempelkan poster disekitar pemukiman warga mengenai proker yang akan dilaksanakan selama berada disana termasuk juga rumah belajar. Banyak sekali orang tua murid yang antusias ketika mengetahui akan hal tersebut begitu juga dengan para siswa sekolah dasar yang ada disana.

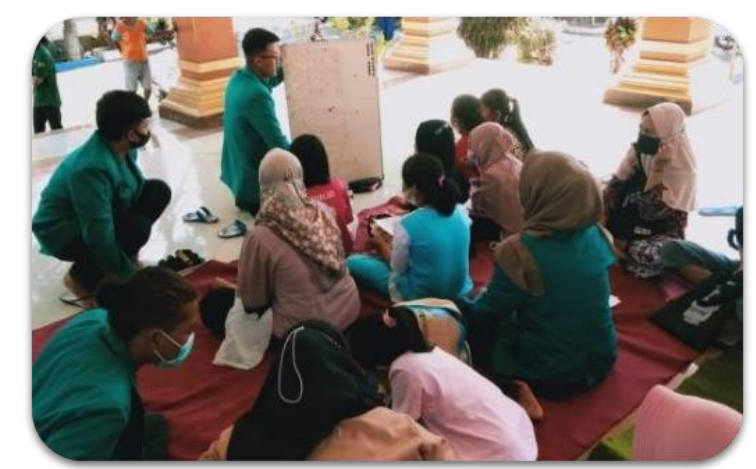

Gambar 1. Pengenalan rumah belajar kepada para murid dan orang tua

\section{Pelaksanaan Rumah Belajar Bagi Para Siswa Sekolah Dasar}

Rumah belajar akan bertempat di pendopo balai Desa Gunungrejo, Kecamatan Singosari, Kabupaten Malang. Ada tiga kali pertemuan yang diadakan dalam satu minggunya yakni pada hari senin sampai dengan rabu. Untuk hari senin dan rabu yaitu untuk semua mata pelajaran kecuali pendidikan jasmani dan untuk hari selasa yaitu pendidikan jasmani dimana selruh murid melakukan senam bersama ketika pagi sehingga mereka tidak akan merasa bosan saat sedang belajar (Lidiawati \& Muhammad, 2021).

Pertama, para siswa akan dikelompokkan berdasarkan tingkatan kelas dari kelas 1-6 sekolah dasar. setiap kelompok didampingi oleh 2 sampai 3 mahasiswa yang akan membantu untuk mengerjakan pekerjaan rumah sekaligus menjelaskan materi yang sekiranya belum dipahami oleh para murid dengan cara diskusi. Jadi siswa tidak hanya pasif mendengarkan saja tetapi ikut belajar untuk menyelesaikan masalah yang ada. Sehingga materi yang diberikan juga lebih mudah diserap oleh para siswa.

Pada minggu terakhir pertemuan akan diadakan kuis sesuai dengan tingkat kelas masing-masing untuk melatih jiwa kompetisi siswa dan juga mengukur sudah sampai mana perkembangan siswa ketika belajar di rumah belajar yang didirikan oleh mahasiswa. Dari hasil yang dilihat kemampuan siswa sudah jauh berkembang dibandingkan ketika minggu-minggu awal dimana mereka sama sekali belum menguasai materi-materi yang ada. Ini membuktikan bahwa dengan adanya rumah belajar bisa membantu siswa untuk lebih bersemangat lagi dalam belajar dikarenakan lingkungan, suasana dan bertemu orang baru membuat mereka semangat ketika menerima materimateri yang diberikan. 


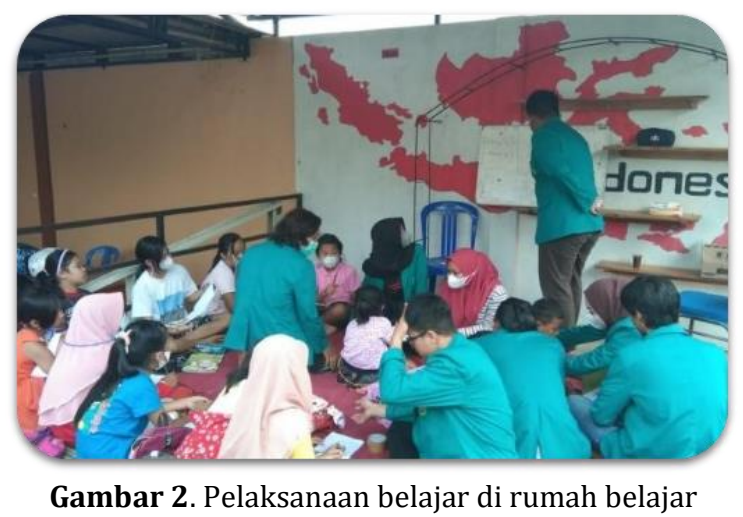

\section{KESIMPULAN}

Dapat disimpulkan dari hasil pembentukan rumah belajar yang dilakukan oleh mahasiswa adalaha sebagai berikut: (1) Pembagian brosur dan penempelan poster mengenai rumah belajar yang akan dibentuk oleh mahasiswa KSM-Temati Unisma sudah mendapat respon yang baik sejak awal dari para orang tua maupun siswa. Sehingga para siswa bisa belajar dengan lingkungan dan suasana yang baru dengan begitu semangat belajar mereka akan terbentuk kembali seperti saat melakukan tatap muka. (2) Dengan adanya rumah belajar tersebut, terbukti bahwa semangat belajar dan jiwa kompetisi siswa bisa meningkat kembali sehingga mutu pendidikan bisa tetap terjaga meskipun para siswa masih harus melakukan pembelajaran jarak jauh dengan daring.

\section{DAFTAR RUJUKAN}

Lidiawati, S. D., \& Muhammad, H. N. (2021). Efektivitas pembelajaran daring selama pandemi pada mata pembelajaran pendidikan jasmani olahraga dan kesehatan. Jurnal $\begin{array}{llll}\text { Pendidikan Olahraga Dan } & \text { Kesehatan, }\end{array}$ https://ejournal.unesa.ac.id/index.php/jurnal-pendidikanjasmani/article/view/39512

Nafrin, I. A., \& Hudaidah. (2021). Perkembangan Pendidikan Indonesia di Masa Pandemi Covid-19. Edukatif: Jurnal Ilmu Pendidikan, 3(2), 456-462. https://doi.org/10.31004/edukatif.v3i2.324

Palupi, T. N. (2020). Tingkat Stres pada Siswa-Siswi Sekolah Dasar dalam Menjalankan Proses Belajar di Rumah Selama Pandemi Covid-19. Jurnal Psikologi Pendidikan Dan Pengembangan $S D M$, $9(2)$,

18-29. https://ejournal.borobudur.ac.id/index.php/psikologi/article/view/716

Rosyidah, A. N. K., Affandi, L. H., Erfan, M., Oktaviyanti, I., Maulyda, M. A., \& Hamdani, I. (2021). Pengentasan buta aksara berbasis pendekatan "semua anak cerdas" untuk guru SD. Jurnal Inovasi Hasil Pengabdian Masyarakat (JIPEMAS), 4(3), 362-377. https://doi.org/10.33474/jipemas.v4i3.10884

Suhartoyo, E., Wailissa, S. A., Jalarwati, S., Samsia, S., Wati, S., Qomariah, N., Dayanti, E., Maulani, I., Mukhlish, I., Rizki Azhari, M. H., Muhammad Isa, H., \& Maulana Amin, I. (2020). Pembelajaran Kontekstual Dalam Mewujudkan Merdeka Belajar. Jurnal Pembelajaran Pemberdayaan Masyarakat (JP2M), 1(3), 161-164. https://doi.org/10.33474/jp2m.v1i3.6588 